Article

\title{
Sharing Economy in Russia: Current Status, Barriers, Prospects and Role of Universities
}

\author{
Svetlana Revinova ${ }^{1, * \mathbb{D}}$, Svetlana Ratner ${ }^{1,2}$, Inna Lazanyuk ${ }^{1}$ and Konstantin Gomonov ${ }^{1}$ \\ 1 Department of Economic and Mathematical Modelling, Peoples' Friendship University of Russia (RUDN \\ University), 6 Miklukho-Maklaya Street, 117198 Moscow, Russia; ratner-sv@rudn.ru (S.R.); \\ lazanyuk-iv@rudn.ru (I.L.); gomonov-kg@rudn.ru (K.G.) \\ 2 Economic Dynamics and Innovation Management Laboratory, V.A. Trapeznikov Institute of Control \\ Sciences, Russian Academy of Sciences, 65 Profsoyuznaya Street, 117997 Moscow, Russia \\ * Correspondence: revinova_syu@pfur.ru; Tel.: +7-495-433-4065
}

Received: 13 May 2020; Accepted: 11 June 2020; Published: 14 June 2020

check for updates

\begin{abstract}
Nowadays, information technology and the Internet are becoming a driver for a shared consumption economy (sharing economy). The paper aims to analyse the current level of use and prospects for the development of models of the sharing economy in Russia. We identify the effects of sharing consumption for the circular economy and study factors that stimulate the use of peer-to-peer models. One of the study's tasks was to investigate the involvement of the young generation in the sharing economy, as the most promising part of the population. The study is based on the analysis of open Internet sources on the operation of sharing platforms in Russia and a survey among students at two Russian universities (RUDN University in Moscow and Kuban State University in Krasnodar) to identify the awareness of young people regarding sharing platforms. Analysis of the current state of sharing in Russia showed that the use of most types of sharing is at an initial stage. At the same time, the prospects for economic growth and population development are quite high. The article identifies several effects of digital platforms for sustainable development, the main of which are informed consumption and production. For the further growth of users of the sharing economy, the authors highlight the level of penetration of the Internet and the need for high-quality services on digital platforms. Educational organisations can also become a platform for the development of models of the sharing economy by involving students in sharing processes, as demonstrated by the survey.
\end{abstract}

Keywords: sustainable consumption; sharing economy; circular economy; digital platforms; carsharing; ridesharing; homesharing; foodsharing; $\mathrm{C} 2 \mathrm{C}$ platforms

\section{Introduction}

In September 2015, at the United Nations New York Summit on Sustainable Development, 193 UN member states formally adopted the new Sustainable Development Program, "Transforming our world: the 2030 Agenda for Sustainable Development". This agenda includes 17 goals and 169 targets [1]. The objectives of this program are to improve the quality of life and prospects for all people. One of the goals of sustainable development is to ensure the transition to rational consumption and production patterns. This goal implies a transition to the environmentally sound use of all resources, reducing waste by taking measures to prevent its generation, and reducing, processing, and reusing waste throughout the entire product life cycle. The concept of a circular economy or closed-loop economy is connected with the solution of these problems. A circular economy is consistent with Goal 12 "Responsible production and consumption" of the UN Global Program "17 Sustainable Development Goals" (https://www.undp.org/content/undp/en/home/sustainabledevelopment-goals/goal-12-responsible-consumption-and-production.html - UN Goal №12). A 
circular economy is based on the conservation and reuse of resources. Additionally, it solves another critical problem-overproduction. Today, the economic sector consumes more resources and produces more goods than people need. A circular economy is a policy approach and business strategy that aims to improve resource productivity, promote sustainable consumption and production, and reduce environmental impacts [2].

However, the transition to business models of the circular economy from traditional linear ones is not an easy task. The development of a circular economy requires the restructuring of the logistics and production chains, changes in approaches to planning production systems, as well as radical changes in consumer behaviour patterns that should become sustainable. Sustainable consumption is closely linked to a shared consumption economy (sharing economy). The sharing economy has the potential to realise more sustainable consumption practices [3]. It contributes to a more efficient allocation of resources and reduces the environmental burden. In addition, it increases the level of trust in society [4]. Such a system allows us to switch to more rational consumption principles, which is consistent with the goal of sustainable development [5].

The scale of the development of the sharing economy substantially depends on the availability of digital technologies that unite people and businesses. Digital platforms can be used through computers and smartphones; they unite people, assets and data, creating fundamentally new ways of consuming goods and services. They reduce the barriers for companies in creating value by changing their personal and professional space [6]. Besides, the advantages of the digital economy can be used not only for the development of joint consumption but also for responding to such vital challenges of our time as reducing unemployment, ensuring access to healthcare, affordable energy, ending environmental degradation, etc. The digital economy is becoming the basis for the introduction of rational and shared consumption and, at the same time, it opens up access to the effective implementation of projects in the field of closed-loop economy. In the European countries, the development of the circular, sharing and digital economy go together, complementing and enhancing each other's positive effects. Only the digital economy has received significant development in Russia, as confirmed by studies of Russian authors [7]. At the same time, the Russian Federation pays excellent attention to the development of the digital economy. Digital platforms are being actively implemented in all areas of life: education, healthcare, public administration, etc. Such an active penetration of digital technologies into all spheres of life becomes a driver for the gradual development of a sharing economy and, as a result, a circular economy. In this sense, the Russian experience is unique in its way, as it allows us to gain new knowledge about the possibilities of transition to sustainable consumption. Mainly it happens with the help of digital technologies, without the powerful influence of other factors-favourable institutional conditions, large-scale educational campaigns, legislative restrictions, etc.

Nowadays, there are many articles on the assessment and development prospects of the digital economy in Russia. At the same time, the Russian sharing economy has appeared quite recently as an object of scientific research and has not been studied. The available scientific articles are mostly descriptive. There is a lack of papers that considers sharing economics in the context of sustainable development. This work is pilot research in this area in the Russian Federation. The purpose of this paper is to fill these knowledge gaps by empirically exploring the perspective of using sharing platforms in Russia. This paper aims to analyse the current level and prospects for the development of models of sharing economy in Russia. We also tried to identify the effects of its use on the circular economy, as well as to study factors that stimulate the use of sharing models. One of the tasks of the study was to see the involvement of the young generation in the sharing economy, as the most promising part of the population. The rest of the paper is organised as follows: Section 2, an analysis of the evolution of the development of digital models to organise the joint consumption of resources; Section 3 gives a brief overview of the research methodology and data; in Section 4 we present the results of the analysis of the current level and prospects for the development of a sharing economy in Russia, as well as the results of a survey of the most promising group of users of sharing platforms; Section 5 discusses the results of the study and gives some recommendations on organising the process 
of involving young people in the sharing economy; the final section concludes the study and discusses its added value for academic literature.

\section{Evolution of Main Ideas and Current State of Sharing Economy: A Literature Review}

The concept of the sharing economy is not new. Before the rapid spread of information technology, there were libraries, rental offices of various equipment and machinery, second-hand stores and mutual assistance cash desks. The basis of such business models is the presence of underutilised assets (goods, capital, etc.) and the presence of a place (platform) where the owners of such assets and persons can meet $[8,9]$. The economy of joint consumption suggests that it is more profitable for an individual or an entire business to get temporary access to a product or service than to own them fully. Moreover, this applies to large and small companies, wealthy citizens, and those below the poverty line.

People started talking about a new concept of economy for the first time in 1970. The authorship of the approach and the names it was attributed to were of economists John Lyle and Walter Steiner, but a few years earlier, economist and philosopher Kenneth Boulding began to develop a model of a closed-loop economy as a replacement for the concept of economic growth. Rachel Botsman and Roo Rogers developed the concept of co-consumption in 2010 in the book What's Mine Is Yours: The Rise of Collaborative Consumption [10]. However, this concept had been mentioned earlier; for example, in the article by Yochai Benkler «Sharing Nicely: Shareable goods and the emergence of sharing as a modality of economic production» [11]. A shared consumption economy contributes to a more efficient allocation of resources and a reduction in environmental pressures, and it increases the level of trust in society [4]. Such a system allows us to switch to more rational principles of consumption which is consistent with the goal of sustainable development [5]. Concepts such as sustainable design, green products, clean technologies and eco-friendly processes have pushed organisations to opt for a change in management initiatives to accomplish sustainable development [12]. The sharing economy is an economic and social system that relies on the concept of shared use of physical and human resources [13]. The sharing economy consists of various practices, activities, and industries and includes numerous organisations with varying types of for-profit and non-profit initiatives [14,15]. The sharing economy, in addition to positive value creation (i.e., benefits), is in some cases linked to value destruction [16], such as additional pollution creation, inferior product and service quality, bad working conditions, health and safety problems. It also involves paradoxes and tensions leading to some negative consequences; for instance, new forms of inequality and polarisations of ownership [17-19]. Relevant findings [20] suggest that sustainability connotation closely connects to specific sectors such as fashion, on-demand services, and logistics. Not all business models of the sharing economy are sustainable, but most of them still create lasting value [20-23]. Experts at the World Economic Forum define the sharing economy as an economic activity based on online platforms and based on the joint consumption of underutilised assets on a reimbursable or free basis [24]. An essential aspect of digitalisation's impact on the solution of environmental problems is the possibility of using virtual communication for an organisation's sharing economy practices that contribute to the reduction of waste [25]. The digital sharing economy enables its members to find temporary work, earn extra income, and gain access to resources that could not otherwise be obtained [21]. The sharing economy is also called peer-to-peer (P2P) economy and collaboration economy, which allows the sharing of physical products and services [9]. Websites and apps such as Uber, Airbnb, and Lyft are platforms that support a sharing economy where individuals can buy and share products or services [26].

The sharing economy is a phenomenon that provides full access to goods and services that are not used by their owners or are used very rarely. In this way, accessibility becomes more important than ownership. The sharing economy is based on the use of information technology to provide people with information on optimising resources by moving surplus goods and services $[8,27]$. Both the sellers and the consumers of products and services are involved in the sharing economy; i.e., the joint production, consumption, and distribution of goods and services are implied [28,29]. Common use occurs in organised systems or networks where the participants carry out sharing activities such as 
renting, lending, trading, exchanging goods, services, transport solutions, space or money [30]. Thus, there is a need for such business models that can satisfy this condition. The widespread dissemination of the Internet contributes to this. One of the central business models in the sharing economy is the marketplace/platform economy [31]. The platform is a market space where customer relationships are automated in most cases. The digital platform successfully facilitates access to transactions.

The sharing economy is present in five primary sectors: housing, transportation, home services, professional services and finance. Some studies show that sharing reduces the number of goods to be produced. In contrast, others question this effect in sectors such as transport. The services of a joint economy impede the use of public transport in favour of private transport, which will increase urban pollution and congestion. From a labour point of view, there seems to be a consensus in the scientific literature about the sharing economy's enormous potential to create jobs. Meanwhile, in the financial sector, the emergence of platforms has facilitated access to credit for financing projects by individuals [29]. Studies on public behaviour show that return on investment is an essential practice for sustainable supply chain management, helping to share economic platforms to make better use of assets and improve financial performance [32].

Based on this assessment, business models in the sharing economy were identified as sustainable business models-business models that create social and environmental value in addition to financial value. However, with the expansion of production, there are environmental risks [21]. Some studies show that in connection with environmental risks, organisations implementing sharing should develop a social licence to operate or ensure the following of the standards and operating procedures by its employees, stakeholders, and the general public [33]. An example of this is Airbnb [34] which connects homeowners with visitors. Another example is BlaBlaCar, a company facilitating the transport of people between different locations. The priority in using such platforms today is to gain economic benefits from social or environmental aspects [20,32].

However, risk modelling of the sharing economy from tourism [34], using structural equations, showed that in terms of privacy and financial risks, these is a marked decrease in intention to use a general use economy. However, physical and performance risks are positively related to behavioural intention or desire. This situation may be due to a disruptive innovation economy. At the same time, a trend towards social responsibility and environmental protection is observed worldwide which will lead to even more active use of digital platforms. Simultaneously, the ecological and social effects of the sharing economy will depend most importantly on institutional changes still to come $[4,21,22]$. Some academic studies indicate the rapid growth of effective business models in the sharing economy. Such business models have a sustainable value expressed in reducing environmental impact and providing social welfare and stable economic benefits [22]. The amount of global food waste is 1300 million metric tons, which is about $95-115 \mathrm{~kg}$ per person per year in Europe and America; on average in sub-Saharan Africa, South Asia and Southeast Asia, it is 6-11 kg per person per year. Therefore, we consider it is necessary to introduce sharing in the food sector. According to the data, $40 \%$ of food losses in developing countries occur at the stages of collection, processing and preparation [35]. In the article by Waqar Nadeem, Mari Juntunen, Farid Shirazi, Nick Hajli [4], a model is constructed that explains the formation of intentions to jointly create value for consumers which shows that social support influences ethical perceptions and affects the co-creation of value.

There are various attempts to evaluate the contribution of the sharing economy to the economies of countries. According to World Bank estimates, China is the world leader in the sharing economy. In 2018, the volume of China's joint consumption economy was estimated at more than 230 billion US dollars or $1.67 \%$ of the country's GDP. This is due, firstly, to the high prevalence of mobile payments (in 2016, the volume of transactions in China almost exceeded by almost 50 times the level in the USA), and secondly, to state support and the desire of the government to cooperate with companies in the sphere of sharing economy [36]. The organisation Timbro compiled an index to assess the level of development of the sharing economy according to another methodology. The Timbro Sharing Economy Index is the first global index of the sharing economy. The index has been compiled using 
traffic volume data and scraped data and provides a unique insight into the driving factors behind the peer-to-peer economy [37]. The leader among the 213 countries in the distribution of the sharing economy is Iceland.

The five leaders also included the Turks and Caicos Islands, Malta, Montenegro and New Zealand. The Russian Federation occupies the 105th position. In 2016, the volume of the economy of joint consumption in the EU countries was estimated at EUR 26.5 billion (0.17\% of EU-28 GDP in 2016). The most developed sharing economy markets are in France (EUR 6.5603 billion), the UK (EUR 4.6377 billion), Poland (EUR 2.7366 billion) and Spain (EUR 2.5243 billion). In general, the seven largest collaborative economy markets in the EU (France, UK, Poland, Spain, Germany, Italy and Denmark) represent about $80 \%$ of the total collaborative revenues of the EU-28 in 2016 . At the same time, the level of development of the collaborative economy in the EU varies significantly. In Estonia, Poland, Latvia, Luxembourg, the Czech Republic and Sweden, the collaborative economy plays a significant role in the overall economy-these countries perform above the EU-28 average.

On the other hand, in Denmark, Ireland, Romania, Slovenia and Belgium, the collaborative economy plays a relatively minor role in the overall economy [38]. According to the PricewaterhouseCoopers forecast, the revenue of companies in the joint consumption economy will increase by 22 times and reach $\$ 335$ billion by 2025 [39]. One of the drivers of such rapid growth is the availability of the sharing economy to ordinary people. The widespread distribution of the Internet ensures this accessibility. Access to the network can be carried out through personal computers and mobile phones and other gadgets. It was the Internet that became the basis for the emergence of such a new business model as a digital platform. The digital platform brings together service providers and consumers $24 / 7$ on their website on the Internet (this can be a website or a mobile application).

A channel or platform is the basis for a business market model where customer relationships are automated in most cases. The operator of the marketplace platform succeeds in facilitating access to transactions [40]. Some authors [21,23,29,41-43] point out that several areas of sharing economies are distinguished where digital platforms have the most exceptional prospects for a circular economy. We also believe that digital platforms play an essential role in some types of sharing: carsharing, homesharing, ridesharing, foodsharing, etc. Moreover, the sharing platforms themselves can significantly increase resource use efficiency and can be an effective way to reduce food waste. In our opinion, the following types of sharing are the most developed in Russia today:

- Carsharing - per-minute payment for a car.

- Ridesharing, carpooling - search for a fellow traveller to share the fare for the trip.

- Homesharing-rental apartments, houses, villas, etc., anywhere in the world.

- Coworking-time-based rental of a workspace.

- Foodsharing-sharing products.

- $\quad$ C2C platforms are uniting Internet users for the exchange of goods and services.

Selling used items is one of the most sought-after services in the global market. One of the most famous sites is the American eBay. The number of active eBay buyers worldwide has reached 182 million people, and the total turnover in 2018 amounted to $\$ 95$ billion [44]. The idea of selling unnecessary products is not new. In the pre-digital era, such a service was provided by thrift stores (intermediary). Nevertheless, there were significant limitations: the seller, intermediary and buyer had to be next to each other. This sharing industry's success is mostly due to the emergence of digital platforms that have opened up the market and made it unlimited.

Carsharing is also not new. Car rental was typical in developed countries until the advent of the Internet. However, before the advent of digital platforms, there were significant restrictions. In essence, it was necessary to come to the company, fill out documents, make a payment and after use hand over the car. Digital platforms enable using geolocation to find the nearest car, make a payment online and get access to it. Carsharing is developing dynamically around the world (Figure 1.) According to Statista, the number of users of this service will reach 36 million people by 2025 . 


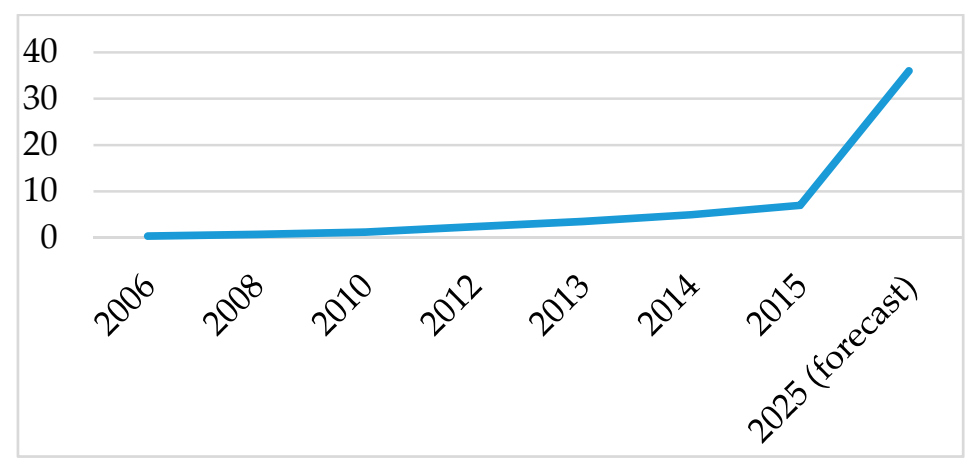

Figure 1. Number of carsharing users worldwide from 2006 to 2025 (in millions) [45].

A significant advantage of carsharing development in large cities is a reduction in overall traffic by optimising logistics. Using electric cars for carsharing gives a significant additional effect of reducing the environmental load [46].

Homesharing is becoming more and more popular all over the world. The globalisation and development of the tourism industry have had a significant influence on the development of homesharing $[9,34,47]$. According to Airbnb, every night, 2 million Airbnb users stop in one of the world's 100,000 cities. In 191 countries, one of 6 million ads can be selected [48]. Web scraping the Airbnb website in fall 2018 and 2019 resulted in datasets on 5.7 million listings, including 3.6 million active listings that have been rented out in the last year. The numbers of Airbnb listings in countries depend on the level of economic development and the size of inbound tourism. One third of Airbnb supply is located in big cities, another third near seacoasts [49]. Placing tourists with residents generally reduces the burden on the environment, reducing the need to build new hotels, which may not be full after completion of events [47,50]. A limitation on the use of homesharing places trust in both the landlord and the tenant $[34,51]$. Today, discussions are ongoing on the legal status of such a business but no legislative decisions have been made [33,52].

One of the newest types of sharing that are gaining momentum is foodsharing. According to the Food and Agriculture Organization of the United Nations (FAO), about one third of produced food is wasted globally (approximately 1.3 billion metric tons annually), which is not only an economic but also an environmental problem [35]. In industrialised countries, over $40 \%$ of food losses occur at the retail and consumer level [53], so the development of sharing platforms can have a significant impact on reducing food waste and losses. Today, food waste prevention is an integral part of the EU Commission's new Circular Economy Package to stimulate Europe's transition towards a circular economy.

\section{Materials and Research Methods}

The authors produced the study in two stages. The first stage involved a review of open sources of the Internet-based platforms for exchange in Russia. The processing of the obtained quantitative data was carried out using descriptive statistics methods, and the qualitative data were processed using systematic and comparative analysis methods. For the analysis, we used statistical data and analytical materials from open sources related to assessments of the use of digital platforms, the degree of involvement of the population, and business in the digital and sharing economy. Data collection was carried out in January-February 2020. As open data sources, we used the websites of international organisations: the European Commission, Publications Office of the EU, the World Economic Forum; providers of market and consumer data: Statista; international consulting companies: Goldman Sachs and PricewaterhouseCoopers. The Russian data sources were the Federal State Statistic Service [54], the largest Russian bank Sberbank, the Association of Electronic Communications [55], the Analytical Center under the Government of the Russian Federation, the Data Insight research agency, the independent analytical centre and consulting company TIAR-Center. To evaluate data 
on the use of sharing platforms, we analysed reports provided by the most popular companies in Russia: BlaBlaCar, Airbnb, Avito and eBay. Additionally, the work used data provided by two Russian universities: RUDN University and Kuban State University.

In the second stage, to clarify the awareness and involvement of young people in the digital sharing economy, a survey was conducted among students at RUDN University (Moscow) and Kuban State University (KubSU, Krasnodar). Several reasons explain this choice of the pilot group of respondents. In most cases, students do not have high incomes. They, therefore, have more significant economic incentives for the active use of sharing models than a better-off part of the population in an older age group. According to the investment company Goldman Sachs's report, millennials, a group to which our respondents belong, do not want to buy anything tangible. Still, they continuously use services that provide them with access to any goods without the burden of ownership [56]. This also applies to renting apartments, cars, or products. Secondly, residents of Moscow, the city with the most developed digital infrastructure and innovative social environment, have more opportunities for the active use of models of sharing economy. In terms of the development of digital infrastructure in most indicators, the Krasnodar Region is the third region of Russia after Moscow and St. Petersburg. However, in terms of the well-being of the population, it has much more modest indicators (Table 1). Therefore, comparing the results of studies obtained in these regions may provide additional data on the factors affecting the development of sharing models of consumer behaviour.

Table 1. Statistical indicators of the development level of digital infrastructure and the welfare of the population in the regions of respondents' residence.

\begin{tabular}{|c|c|c|}
\hline & Moscow & Krasnodar Region \\
\hline Percentage of population using the Internet, \% & 88.3 & 91.3 \\
\hline Percentage of people using the Internet every day, $\%$ & 75.5 & 78.9 \\
\hline The number of connected subscriber mobile devices per 1000 population & 2890.9 & 2439.5 \\
\hline $\begin{array}{l}\text { The number of active mobile subscribers } \\
\text { Broadband Internet access per } 100 \text { population }\end{array}$ & 117.1 & 108.2 \\
\hline The income per capita, rubles per month & 68,386 & 34,372 \\
\hline Real cash income of the population, $\%$ of the previous year & 101.8 & 101.1 \\
\hline $\begin{array}{c}\text { The share of purchase of goods and payment for services in the cost } \\
\text { structure, } \%\end{array}$ & 79.2 & 90.9 \\
\hline The share of business income in the income structure, $\%$ & 4.6 & 10.0 \\
\hline The share of social payments in the structure of income, $\%$ & 12.9 & 16.1 \\
\hline
\end{tabular}

Source: Compiled by the authors according to [57].

Thirdly, Moscow students are the group of young people with the highest knowledge and more developed competencies in the digital economy, acquired in the process of study through the constant use of the electronic learning environment introduced at all universities in Moscow. Thus, the selected group of respondents is the most "advanced" in using digital technologies in daily life. Therefore, the barriers to more active use of consumer behaviour sharing models identified in this group will be even more significant for respondents from other groups, and therefore need to be removed as soon as possible. Students in Krasnodar and the Krasnodar Region have more modest opportunities in the development of electronic competencies, which is especially clearly reflected when comparing the universities selected for the student survey. Thus, RUDN University takes 27th place in the ranking of the 50 best Russian universities in the field of information technology; Kuban State University was not included in this rating (https://raex-a.ru/rankings/vuz/vuz_it_2019).

The data were collected by personal interviews of small groups of students using a structured questionnaire containing mostly closed yes or no questions (Appendix A). The traditional form of a personal survey in the case of small- and medium-scale research from the methodology acquires the main features of the case study: the possibility of combining quantitative and qualitative approaches and the ability to study phenomena in a real-life context [58]. When the interview is conducted by a lecturer who directly teaches students, as a rule, he knows them well enough personally, which allows 
the exclusion of some personal questions (for instance, questions about income level or place of living) from the questionnaire. However, the study's speed, in this case, is slow, and the sample size is usually relatively small. A method for interviewing small groups (up to 10 people) is applied to increase the study's speed. With this approach, the respondent increases the degree of anonymity of participation in the survey (compared to a personal survey). However, at the same time, it remained possible to clarify the questions and the proposed answer options, their context and the probability of misinterpretation of the questionnaire was reduced. The interviewer can control the results initially, and the response rate is usually close to $100 \%$. The study was conducted in March 2020. Before the survey was administered to participants, a pilot survey of 50 undergraduate students was first conducted at RUDN university to check the survey for readability and clarity. Then all authors of this study collected data in the groups of students they currently teach. The final referent group consisted of young people aged 18 to 27 years old (Figure 2), currently living in Moscow (a total of 150 respondents) and Krasnodar (a total of 60 respondents). The distribution of respondents by gender is $65.4 \%$ female vs. $34.6 \%$ male. The income level mainly corresponds to the average level in the region.

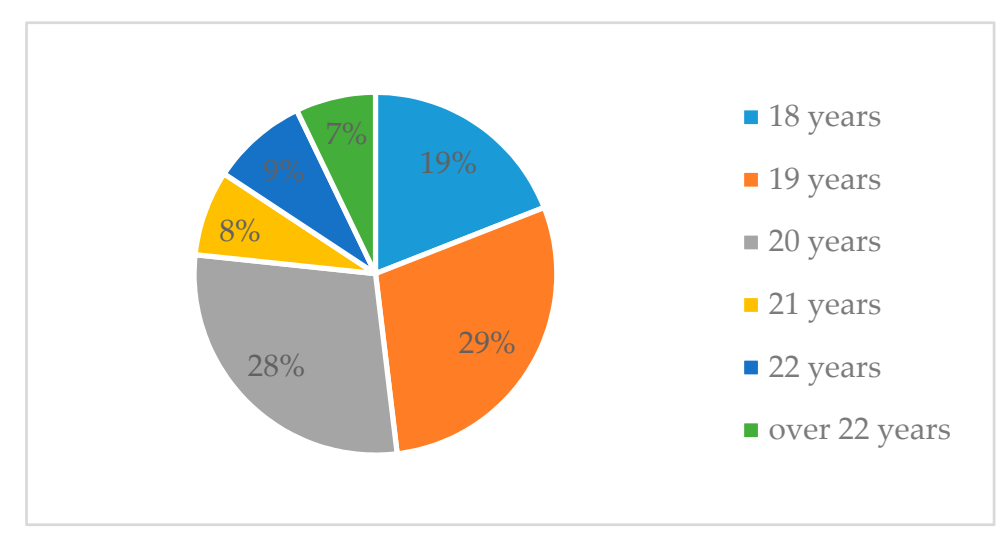

Figure 2. The age structure of respondents.

The questions were divided into three groups: (1) Awareness of the types of sharing and digital platforms; (2) Current use of such platforms; (3) The intention to use these platforms in the coming year. The processing of the survey results was carried out through descriptive statistics.

\section{Results}

\subsection{Open Source Data Analysis Results}

An essential prerequisite for the development of a sharing economy in Russia is the National Digital Economy Program [59]. Digital platforms are an alternative to traditional models that gain a competitive advantage due to the Internet. The digital literacy of the population is growing, and an increasing number of users are easily using Internet applications. Digital has become an integral part of the learning process in schools, universities, and self-education [60]. According to estimates of the TIAR Center (the Russian independent analytical centre and consulting company), the volume of transactions on the leading platforms of the sharing economy in Russia in 2018 amounted to about 511 billion rubles ( $\approx \$ 7.6$ billion), which is $30 \%$ more than in 2017 . The overwhelming share was occupied by the sale of products through $\mathrm{C} 2 \mathrm{C}$ sites (Table 2). 
Table 2. The volume of transactions in some sectors, 2018.

\begin{tabular}{ccc}
\hline Sector & Billion Rubles & Billion $\mathbf{\$}$ \\
\hline C2C selling items & 370 & $\approx 5.5$ \\
Ridesharing & 13.7 & $\approx 0.2$ \\
Carsharing & 13 & $\approx 0.2$ \\
Homesharing & 9.8 & $\approx 0.15$ \\
Coworking & 5.7 & $\approx 0.09$ \\
Rental items & 0.2 & $\approx 0.003$
\end{tabular}

Source: Compiled by the authors according to [55].

The key C2C platforms in Russia are Avito and Yula. On such platforms, individuals sell tangible new or used goods to another individual. The number of sellers in this market in Russia amounted to 13.8 million people in 2019 , the number of buyers-11.8. The average purchase receipt amounted to 3210 rubles ( $\approx \$ 48$; this does not include sales of real estate and vehicles) [61]. The Avito platform was launched in 2007 by Swedish entrepreneurs who opened the project, despite the small percentage of Internet users in Russia. Currently, Avito has posted about 51 million ads in various categories: Real estate, jobs, cars and services. Simultaneously, the share of goods is covered in 31 million ads-about $60 \%$ of all ads posted on the site [62]. Yula is an ad service launched by Mail.ru Group in 2015. By the number of monthly users, it is only slightly inferior to its main competitor. Yula is visited monthly by 27 million users. Besides, ad growth rates for Yula are higher than for Avito [63]. The proportion of sellers of such goods in small cities is actively growing. In two years, the share of C2C sellers in the capital and regional centres decreased by 10\% and amounted to 70\% in 2019 (Figure 3.)

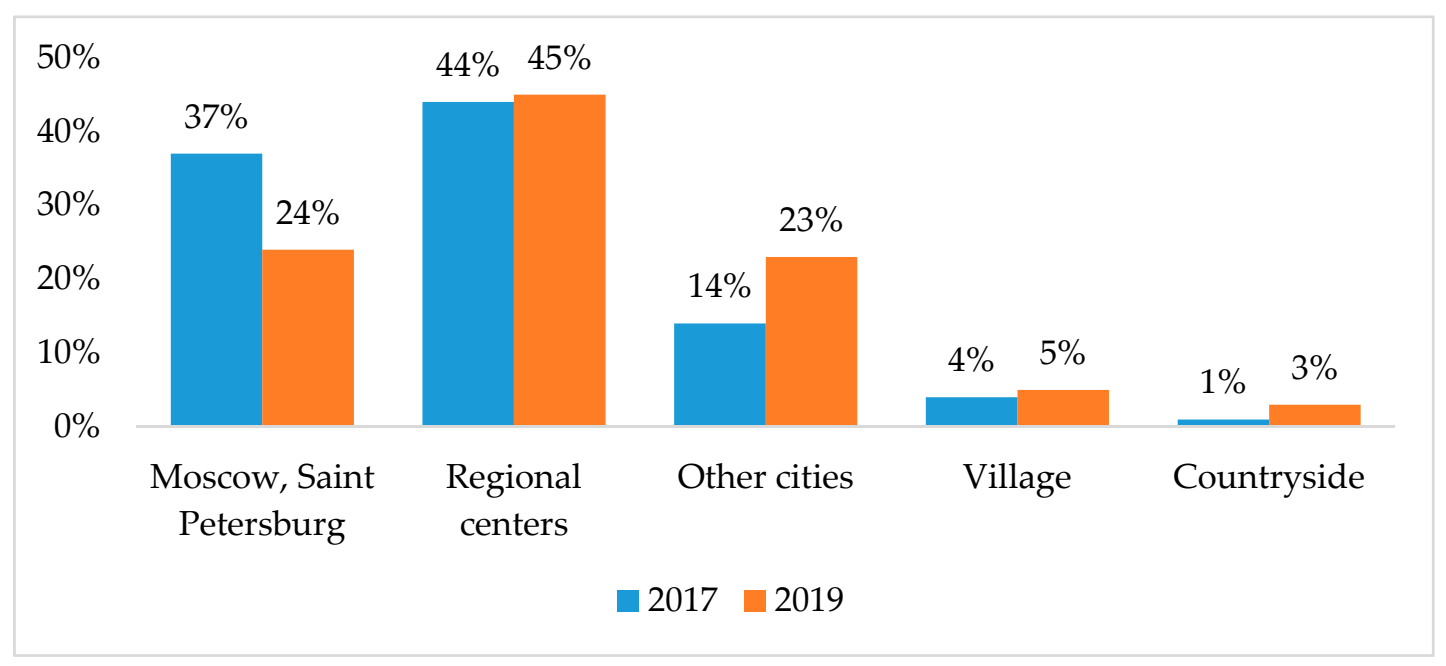

Figure 3. Distribution of private sellers by type of community. Source: Compiled by the authors according to $[61,64]$.

We note that goods are currently transported throughout Russia; however, earlier purchases were made mainly within the same settlement. This trend will intensify with the further penetration of digital technology into remote centres and rural areas. As for the contribution of $\mathrm{C} 2 \mathrm{C}$ sales to the circular economy, they give a second life to second-hand products, help in the fight against an increase in garbage, and improve the quality of life of the population, allowing them to purchase the goods they need at lower prices.

Ridesharing (carpooling) in Russia, as well as in the world, mainly specialises in long-distance trips. About 100,000 Russians use this service every day, and that is a tiny share. Ridesharing has not yet penetrated intercity trips, although discussions on this issue are quite active. Ridesharing services occasionally offer incentives to drivers who bring their fellow travellers, which will reduce the number of private cars on the roads. The most common digital ridesharing platform in Russia is the European 
company BlaBlaCar. This service is used by more than 65 million people in 22 countries. The average distance of such trips is $300 \mathrm{~km}$ [65]. The average occupancy rate of a BlaBlaCar vehicle is 3.9 people. In 2018, the usual journey across Russia was $300 \mathrm{~km}$, as well as around the world, for 350 rubles $(\approx \$ 5.2)$. The advantages of using this service for customers are cost savings on personal or public transport, more comfortable and flexible travel conditions. However, ridesharing has non-deliveries associated with the risk of travelling together with a stranger. Moreover, this service is not so popular and well-known, especially in small cities.

In Russia, as in the world, the basis of carsharing is the companies that own fleets and allow users to leave the car in any permitted place within the service coverage area. In 2018, the carsharing market in Russia slightly lagged behind in terms of ridesharing but the situation is changing. In the past year, there has been an explosive growth in carsharing in Moscow and other large cities. According to Sberbank, in December 2017, 51.6 thousand Russians spent 295.3 million rubles ( $\approx \$ 4.4$ million) on short-term car rentals per month; in December 2018, the number increased to 228.8 thousand people. The total expenses for carsharing amounted to 951.5 million rubles ( $\approx \$ 14.2$ million). In January 2019 , this figure had already exceeded 1 billion rubles ( $\approx \$ 15$ million). In mid-2017, five companies were actively working on the market, and in early 2019 there were 13 companies. The key players in this market are the digital platforms Yandex.Drive, BelcaCar and Delimobil. Moscow is the leader among the cities of the Russian Federation (85\%) [66]. By the end of 2018, the carsharing car fleet in Moscow amounted to 16,000 . In all other regions, a total of about 3800. In Moscow, carsharing users made an average of 33 trips per year, in St. Petersburg and the Leningrad Region-21 trips. As a rule, in other regions where there is car sharing, Russians make 18 trips a year. Carsharing services were used at least once by representatives of 83 regions of Russia. The average bill ranges from 183 rubles $(\approx \$ 2.7$, Ufa city) to almost 300 rubles $(\approx \$ 4.5$, St. Petersburg). A typical user spends 3469 rubles $(\approx \$ 52)$ on carsharing per month, the average price of their trip is 260 rubles $(\approx \$ 3.9)$ [66]. At the end of 2019 , there were more than 30 thousand cars in Moscow which were allowed to take first place among the world's cities. Earlier, the Japanese capital of Tokyo was considered the leader in the number of sharing cars, with 20,000 such cars being registered. Carsharing enjoys unprecedented support from city authorities. The advantages for the city include reduced road congestion, leading to a higher quality of life for citizens and reduced environmental pollution, and improved environmental conditions. Consumers of services increasingly refuse to buy or use personal cars. This is especially true for large cities where in recent years there has been a growing lack of parking spaces. Disadvantages of carsharing also exist. They come down to the risks associated with dishonest and neglectful attitudes to other people's property, dangerous driving, the risk of cheating the system, or driving while intoxicated. Companies forced to increase the cost of security due to installing cameras inside the car.

Homesharing has been growing dynamically in Russia over the past few years. In 2018, the growth was by $70 \%$. Experts attribute this growth to major international events, such as the 2018 FIFA World Cup in Russia. The most popular digital platforms in this sector in Russia are Avito, Airbnb and CIAN. Russia has a high share of domestic tourism involving homesharing. Even with the Airbnb service, which specialises in international audiences, the percentage of local travel among bookings in Russia reached 63\% by 2017 [67]. This service is most in demand in St. Petersburg (43\%) and Moscow (25\%) [55] which are large venues for domestic and international events (sports, cultural, scientific, business) and are trendy among Russian and foreign tourists.

There are more and more announcements about the use of space for coworking in large business centres, malls, cafes, etc. Coworking is the space where anyone can find a temporary or permanent workplace for themselves. We used the definition by Bouncken and Reuschl, whereby one aspect of coworking spaces is the sharing of office space; another is the sharing of social spaces beside the office [68]. This phenomenon is relatively new for Russia but is gaining popularity. Prices for such a workplace range from 1500 to 25,000 rubles (from $\approx \$ 22$ to $\$ 373$ ) [69]. However, talking about the development of the coworking market is possible only in Moscow and St. Petersburg (Figure 4). We found that the Moscow government is implementing the project "Moscow: Coworking 2.0" which 
provided the basis for the further introduction of this format in the mainstream infrastructure created to support startups and small businesses.

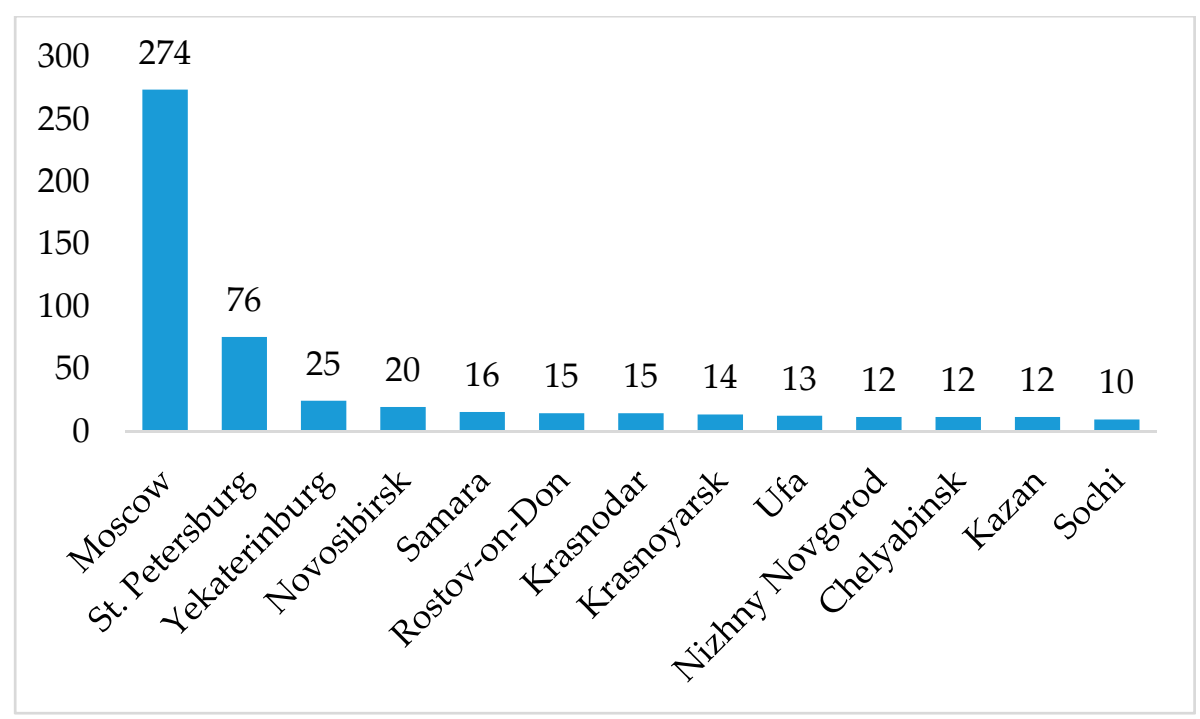

Figure 4. The number of coworking spots in cities of the Russian Federation. Source: Compiled by the authors according to [69].

Coworking enables individual entrepreneurs, a small business or a startup to save money on renting a room. The owner of the room can make a profit by letting out excess space. It ultimately leads to an improvement in the environment by reducing the need for the construction and operation of new office centres. Of course, this type of sharing will be more in demand as private business grows. Digital platforms save time in finding workplaces. For example, on the Kovorkingi.ru platform, information is collected about all the sites in Russia which allows renting a workspace, not only for a business located in this city but also for holding short-term business meetings during business trips, and negotiations in other cities.

In Russia, the rental market for products is at the initial stage of development. On rental platforms, products that are needed once are in demand; for example, repair tools, evening dresses, sports equipment, photo lenses, etc. Companies which make it possible to rent goods have been around for quite some time. Now they have realised all the advantages of digital platforms and are actively involved in sharing along with individuals. Key digital platforms in the Russian market are Avito, RENTMANIA and Next2U. The benefit for participants in this type of sharing is access to the necessary products at a significantly reduced cost. Using this type of sharing, the client acts rationally and environmentally without buying too much and without littering their living space.

An example of a Russian foodsharing system is the digital platform EatyEat. As Olga Sherunkova notes, about 17 million tons of food waste is generated in Russia which is $28 \%$ of the total solid municipal waste (MSW) [70]. Moreover, most of it goes to landfills. In addition to the garbage crisis, such projects can help improve the quality of life for part of the population. Seventeen million tons of food would be enough to feed 30 million people for a year, which exceeds the number of Russians with incomes below the subsistence level. As a result, the development of foodsharing allows us to solve several problems at once. Saved food goes targeted to people. Natural and labour resources are used more efficiently and waste is reduced. The potential is enormous for the introduction of technologies and various services in the field of food distribution.

Our analysis results showed that digital sharing platforms provide advantages for both suppliers and consumers of services and become an essential component of a circular economy or a shared consumption economy. Tables 3 and 4 present the advantages and new features of sharing platforms 
that stimulate their further distribution, constraining their distribution factors and limitations and the effect of such platforms on the circular economy.

Table 3. Benefits of sharing platforms.

\begin{tabular}{|c|c|c|}
\hline Sharing Type & $\begin{array}{l}\text { Benefits for Suppliers of Goods and } \\
\text { Services }\end{array}$ & $\begin{array}{c}\text { Benefits for Consumers of Products and } \\
\text { Services }\end{array}$ \\
\hline $\begin{array}{l}\text { C2C selling } \\
\text { items }\end{array}$ & $\begin{array}{l}\text { - } \quad \text { Extra income for the seller. } \\
\text { There is no need to store } \\
\text { additional products. }\end{array}$ & $\begin{array}{l}\text { - Savings (the price of goods is usually } \\
\text { lower than in stores). }\end{array}$ \\
\hline Ridesharing & $\begin{array}{l}\text { - } \quad \text { Additional income for the seller. } \\
\text { The social aspect. Meeting new people, } \\
\text { communicating with fellow travellers. } \\
\text { Especially relevant for long journeys. }\end{array}$ & 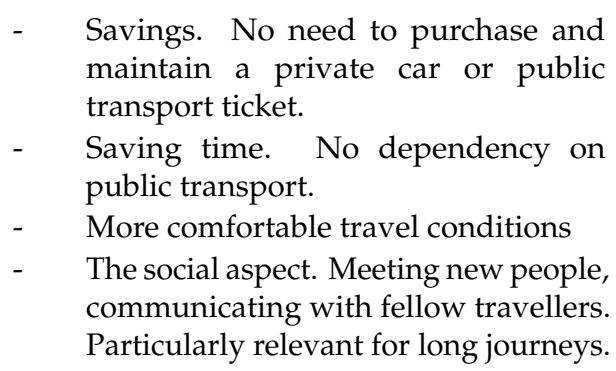 \\
\hline Carsharing & - Extra income for the seller. & $\begin{array}{l}\text { - Saving money. There is no need to } \\
\text { purchase and maintain a personal car. } \\
\text { No parking costs. }\end{array}$ \\
\hline Homesharing & $\begin{array}{l}\text { - } \quad \text { Extra income for the seller. } \\
\text { - } \quad \text { The living area is under supervision. }\end{array}$ & $\begin{array}{l}\text { - Cost savings. The service is } \\
\text { usually cheaper than a hotel. No } \\
\text { need to purchase and maintain } \\
\text { additional housing in case of } \\
\text { long-term employment. }\end{array}$ \\
\hline Coworking & Extra income for the seller. & $\begin{array}{l}\text { - } \quad \text { Quick room search. } \\
\text { Saving money. Lack of additional } \\
\text { expenses (workspace has already been } \\
\text { drawn up). } \\
\text { - The possibility of short-term leases } \\
\text { (less than a day). }\end{array}$ \\
\hline Rental items & Extra income for the seller. & $\begin{array}{l}\text { - Savings (the price of goods is usually } \\
\text { lower than in stores). }\end{array}$ \\
\hline Foodsharing & Extra income for the seller. & Cost savings. \\
\hline
\end{tabular}


Table 4. Features and limitations of sharing platforms.

\begin{tabular}{|c|c|c|c|}
\hline Sharing Type & $\begin{array}{c}\text { Opportunities Provided by } \\
\text { Digitalisation }\end{array}$ & Constraints and Limitations & Effect for a Circular Economy \\
\hline $\begin{array}{l}\mathrm{C} 2 \mathrm{C} \text { selling } \\
\text { items }\end{array}$ & $\begin{array}{l}\text { - Product availability } \\
\text { regardless of location. } \\
\text { - The ability to see } \\
\text { the goods through } \\
\text { IT devices. } \\
\text { - Saving time searching for } \\
\text { a product. }\end{array}$ & $\begin{array}{l}\text { Trust between seller } \\
\text { and buyer }\end{array}$ & $\begin{array}{ll}- & \text { A second life for used items. } \\
- & \text { Conscious consumption. } \\
\text { - } & \text { Reducing the amount } \\
\text { of garbage. } \\
\text { - } \quad \text { Reduced need for production } \\
\text { of goods. }\end{array}$ \\
\hline Ridesharing & $\begin{array}{l}\text { - Saving time searching } \\
\text { for services. } \\
\text { - The ability to choose the } \\
\text { best conditions. }\end{array}$ & $\begin{array}{l}\text { - Trust between the } \\
\text { supplier and the } \\
\text { consumer of the service. } \\
\text { Lack of awareness about } \\
\text { the service. }\end{array}$ & $\begin{array}{ll}\text { - } & \text { Environmental protection. } \\
\text { - } & \text { Reducing air pollution. } \\
\text { - } & \text { Reduced need for new } \\
\text { car production }\end{array}$ \\
\hline Carsharing & $\begin{array}{l}\text { - Geolocation allows us to } \\
\text { find the nearest car. } \\
\text { Carrying out } \\
\text { electronic payment. }\end{array}$ & $\begin{array}{l}\text { Trust between the } \\
\text { provider and the } \\
\text { consumer of the service. } \\
\text { The small interest of } \\
\text { service providers for } \\
\text { its implementation in } \\
\text { small cities. }\end{array}$ & $\begin{array}{l}\text { - Environmental protection. It } \\
\text { has reduced air pollution. } \\
\text { Improving the quality of } \\
\text { life of citizens by reducing } \\
\text { traffic congestion. } \\
\text { - Reduced need for new } \\
\text { car production. }\end{array}$ \\
\hline Homesharing & $\begin{array}{l}\text { - Availability of services } \\
\text { regardless of the } \\
\text { location of the seller } \\
\text { and consumer. } \\
\text { - The ability to see the } \\
\text { house through IT devices. } \\
\text { - Saving time in } \\
\text { finding housing. }\end{array}$ & $\begin{array}{l}\text { - Trust between the } \\
\text { service provider and } \\
\text { the consumer. }\end{array}$ & $\begin{array}{l}\text { - } \quad \text { Environment protection. } \\
\text { Reduced need for the } \\
\text { construction of new areas. }\end{array}$ \\
\hline Coworking & $\begin{array}{l}\text { - Availability of services } \\
\text { regardless of the } \\
\text { location of the seller } \\
\text { and consumer. } \\
\text { Saving time in finding } \\
\text { a room. }\end{array}$ & $\begin{array}{l}\text { - } \quad \text { Lack of awareness about } \\
\text { the service. } \\
\text { - Lack of business interest } \\
\text { in the regions of Russia. }\end{array}$ & $\begin{array}{l}\text { Environment protection. } \\
\text { - Reduced need for the } \\
\text { construction of new areas. }\end{array}$ \\
\hline Rental items & $\begin{array}{l}\text { - Availability of the } \\
\text { product regardless of } \\
\text { its location. } \\
\text { - The ability to see } \\
\text { the goods through } \\
\text { IT devices. } \\
\text { - Saving time searching for } \\
\text { a product. }\end{array}$ & $\begin{array}{l}\text { - Trust between seller } \\
\text { and buyer. }\end{array}$ & $\begin{array}{ll}- & \text { A second life for used items. } \\
- & \text { Conscious consumption. } \\
- & \text { Reduced need for production } \\
\text { of goods. }\end{array}$ \\
\hline Foodsharing & $\begin{array}{l}\text { - Product availability } \\
\text { regardless of location. } \\
\text { - The ability to see } \\
\text { the goods through } \\
\text { IT devices. } \\
\text { - Saving time on } \\
\text { product search. }\end{array}$ & $\begin{array}{l}\text { - Lack of awareness about } \\
\text { the service. } \\
\text { Logistics issues, } \\
\text { especially for } \\
\text { perishable products. }\end{array}$ & $\begin{array}{l}\text { - } \quad \text { Conscious consumption. } \\
\text { - } \quad \text { Waste reduction. } \\
\text { - } \quad \text { Reduced need for } \\
\text { product manufacturing. } \\
\text { - Help for some segments of } \\
\text { the population. }\end{array}$ \\
\hline
\end{tabular}


In our opinion, for the development of the sharing economy essential access to the Internet and the way digital platforms work.The study allowed the authors to draw the following conclusions. Almost all sharing platforms in Russia exist in the form of websites and mobile applications. In the work of these services, of great importance are:

- Providing the most accessible and well-presented information. For example, for assistance in the delivery of residential and non-residential premises, the sale of second-hand goods, etc.;

- Geolocation services. For instance, for carsharing, using geolocation you can see where the nearest free car is located, or the owner company can track the movement of their vehicles;

- Online payments. For example, the sale-purchase of goods between residents of different cities, short-term rental of premises to another town, etc.

The user identification, payment and delivery of goods and services become essential because participants in the sharing economy are most often not familiar with each other. The authors consider that the growth of the sharing economy will continue and the main drivers of such growth can be identified as:

- the growth of the Internet's prominence in Russia, especially in small cities;

- increased public confidence in the products and services provided on the Internet;

- more free circulation of the population with information technologies, in particular with computers, smartphones and tablets;

- increased awareness of the business and the public about new business models;

- $\quad$ the penetration of digital platforms in small towns of the Russian Federation;

- the spread among the population (especially among young people) of fashion trends related to conscious consumption and environmental protection.

A prerequisite for achieving sustainable development goals is the increasingly active participation of the population, business, government bodies and organisations in social processes related to environmental protection and conscious consumption. The media and the Internet play a significant role in these processes. Recently on the Internet have been created websites, groups in social networks, and videos that tell about our planet's problems and options for solving them.. Sharing digital platforms contribute to the growth of the economy of joint consumption and the economy's looping. The development of the sharing economy is connected with the digital economy. The great importance for the development of the sharing economy is the penetration of the Internet into countries, regions, cities and small settlements. The study showed that Moscow and St. Petersburg are the cities most involved in Russia's sharing economy. These same cities are leaders in the penetration of the Internet and their shares exceed the national average (Figure 5).

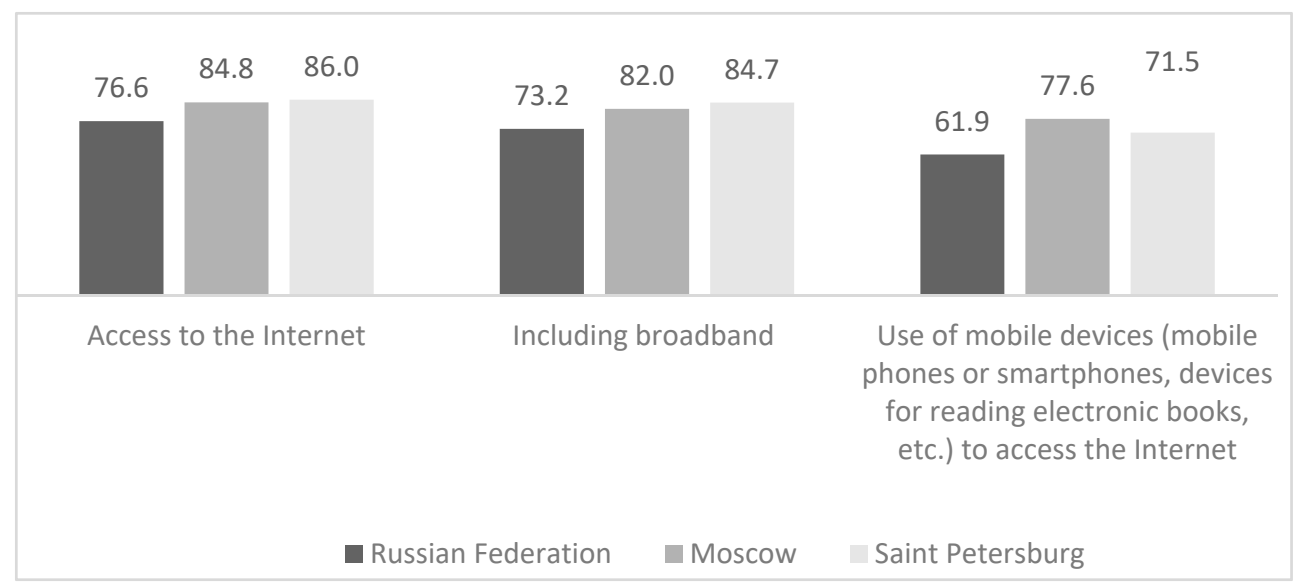

Figure 5. Households with Internet access in the Russian Federation's constituent entities in 2018 (in\% of the total number of households). Source: Compiled by the authors according to [57]. 
Another driver of the growth of the sharing economy based on digital platforms is youth involvement. The younger generation is fluent in using the Internet and is quite familiar with the principles of digital platforms and mobile applications. In other words, the most promising group for engaging in the sharing economy are young people living in large cities with access to handling technology.

\subsection{Survey Results}

Our survey of students from two large Russian universities (RUDN University, KubSU), located in different regions of the country (Moscow and Krasnodar, respectively) showed the following results: the most popular types of sharing are through C2C sites (100\% awareness) and carsharing (93\% awareness) (Table 5).

Table 5. Awareness of types of sharing and experience of use.

\begin{tabular}{|c|c|c|c|c|c|c|}
\hline \multirow[t]{2}{*}{ Type of Sharing } & \multicolumn{2}{|c|}{ Total } & \multicolumn{2}{|c|}{ RUDN University } & \multicolumn{2}{|c|}{ KubSU } \\
\hline & Aware, \% & Use, $\%$ & Aware, $\%$ & Use, $\%$ & Aware, \% & Use, $\%$ \\
\hline $\begin{array}{l}\text { C2C platform } \\
\text { (buying) }\end{array}$ & 100 & 56 & 100 & 53 & 100 & 65 \\
\hline $\begin{array}{l}\text { C2C platform } \\
\text { (renting) }\end{array}$ & 100 & 8 & 100 & 9 & 100 & 5 \\
\hline $\begin{array}{l}\text { C2C platform } \\
\text { (selling) }\end{array}$ & 100 & 56 & 100 & 53 & 100 & 65 \\
\hline Carsharing & 96 & 15 & 97 & 17 & 92 & 10 \\
\hline Coworking & 67 & 43 & 75 & 61 & 47 & 0 \\
\hline Homesharing & 42 & 5 & 33 & 7 & 63 & 2 \\
\hline Foodsharing & 31 & 0 & 29 & 0 & 38 & 0 \\
\hline Ridesharing & 29 & 10 & 22 & 3 & 47 & 28 \\
\hline
\end{tabular}

Source: Compiled by the authors.

Despite the absolute awareness of the possibilities of platforms for exchanging goods, only $56 \%$ of respondents had used them, and in Krasnodar this indicator is higher than in Moscow. This result is most likely explained by the lower solvency of young people in Krasnodar and, consequently, the greater willingness to use sharing models of behaviour when purchasing goods. Students from Krasnodar are more likely to apply for the purchase or sale of goods through a C2C platform. One third of the respondents had used several digital platforms to buy or sell items. Among those who had sold something, 79\% used the Avito platform, 31\%-Yula, 5\%-VKontakte Social Network, 2\%—eBay, $2 \%$-Instagram, $11 \%$ - other sites. They had purchased goods from individuals on Avito- $58 \%$ of those with the shopping experience, on Yula-19\%, on the Social Network VKontakte- $5 \%, 4 \%$ on eBay, 3\%- on Instagram, $6 \%$ - on AliExpress, and on other sites-11\% (Table 6).

Table 6. Using C2C platforms for buying or selling.

\begin{tabular}{ccccccc}
\hline Platform & \multicolumn{2}{c}{ Total } & \multicolumn{2}{c}{ RUDN University } & \multicolumn{2}{c}{ KubSU } \\
\hline & Buying & Selling & Buying & Selling & Buying & Selling \\
\hline Avito & 58 & 79 & 51 & 73 & 74 & 90 \\
Yula & 19 & 31 & 15 & 30 & 26 & 33 \\
Vkontakte & 5 & 5 & 8 & 8 & 0 & 0 \\
eBay & 4 & 2 & 3 & 3 & 8 & 0 \\
Instagram & 3 & 2 & 0 & 0 & 8 & 5 \\
AliExpress & 6 & 0 & 4 & 0 & 10 & 0 \\
other & 11 & 11 & 15 & 13 & 3 & 8 \\
\hline
\end{tabular}

Source: Compiled by the authors. 
The data show that different sites are more often used for shopping. The absolute leader among C2C platforms is Avito. Most of the respondents (96\%) know about carsharing but only $15 \%$ had used it. Such data could also be influenced by the fact that people in Russia obtain rights at the age of 18. Twenty percent of respondents had recently reached this age and $39 \%$ do not have sufficient driving experience. The percentage of people who use carsharing in Moscow is slightly higher than in Krasnodar. The reasons for this are the significantly more extensive fleet in Moscow and the more excellent solvency of the population. The most popular carsharing company among the respondents is Delimobil, $65 \%$ of those who participated in the survey had used this company and in Krasnodar alone this indicator is at $100 \%$. In Moscow, $56 \%$ of students chose Delimobile, followed by Yandex.Drive with $24 \%$. Prospects for carsharing will increase due to gaining driving experience. It will also be facilitated by the widespread rental of bicycles and scooters in large cities which is gaining more and more popularity. Sixty-two percent of respondents have experience using street bike rentals and 37\% have scooters. Furthermore, these numbers will increase with a high degree of probability.

Of particular interest are the data on coworking. Of the $67 \%$ of respondents familiar with this sharing model, $43 \%$ had used it in practice. Moreover, in Krasnodar, this type of sharing was not used by anyone. At RUDN University, more than $60 \%$ of students actively use coworking. Such indicators are explained by the fact that at RUDN University there is a coworking space. It is organised for the students' independent work [71]. The first coworking space with more than 100 jobs appeared at RUDN University in 2017. The new space was designed in the style of a smart office with large round tables, which is available not only for independent but also for group work-where they can prepare for classes, generate new ideas, and conduct brainstorming sessions.

In the new space are installed additional sockets for work on tablets and laptops. Also, there is a possibility to connect to the wireless Internet through five access points for free [71]. More than $10 \%$ of spaces are equipped with stationary computers. The coworking space quickly became popular among students. In 2018, the coworking area was open until late in the evening (until 23.00). Nowadays, coworking zones are present not only in the educational buildings of RUDN University but also in the library and the dormitory buildings. Students can not only use it for study, creativity and work; they can also participate in its arrangement and improvement, submitting their ideas and wishes to the administration. This space allows to prepare for classes jointly, working on scientific or creative projects for students from different groups, courses or faculties. Coworking spaces are popular among students. Thus, students are well acquainted with this type of sharing of the workspace and will undoubtedly use this opportunity in the future.

As for ridesharing, homesharing and foodsharing, these activities have yet to win an audience. Eighty-five percent of respondents knew about BlaBlaCar. However, only 10\% of respondents used ridesharing. Moreover, for Krasnodar students, this service is much more in demand than for Moscow students ( $28 \%$ vs. $3 \%$ ). For residents of the regions, moving from one locality to another is a more relevant service. Moreover, ridesharing makes it possible to save money and drive in more comfortable conditions.

Less than half of respondents ( $42 \%$ ) knew about Airbnb but only $3 \%$ of respondents had used homesharing services. Approximately $50 \%$ had used social network services such as VKontakte and CIAN to rent housing, and the other half had used the Airbnb website.

Among those who had not used digital sharing platforms before, the most significant increase is expected in coworking, but this applies only to Moscow students who are already well-acquainted with this form of using workplaces. Krasnodar students who do not have this experience are still not interested in coworking. The expected increase in users is for sales on $\mathrm{C} 2 \mathrm{C}$ sites, carsharing, etc. (Table 7). 
Table 7. Prospects for the use of sharing platforms in the coming year, not previously used.

\begin{tabular}{cccc}
\hline Type of Sharing & $\begin{array}{c}\text { Going to Use, } \% \\
\text { Total }\end{array}$ & $\begin{array}{c}\text { Going to Use, } \% \\
\text { RUDN University }\end{array}$ & $\begin{array}{c}\text { Going to Use, } \% \\
\text { KubSU }\end{array}$ \\
\hline Coworking & 30 & 42 & 0 \\
C2C platform (selling) & 33 & 65 & 83 \\
Carsharing & 20 & 22 & 13 \\
Homesharing & 7 & 10 & 3 \\
C2C platform (buying) & 30 & 41 & 13 \\
C2C platform (renting) & 16 & 13 & 23 \\
Ridesharing & 4 & 4 & 3 \\
\hline
\end{tabular}

Source: Compiled by the authors.

In general, the least interest of the interviewed group is for ridesharing. As mentioned above, this service is used more for long-distance trips, by an average of $300 \mathrm{~km}$, which may not be so relevant for the Moscow audience but for Krasnodar students it is a necessary measure. An important factor limiting the use of ridesharing is confidence issues. Students would like to know the person with whom they will spend a relatively large amount of time in a confined space: their age, gender, education and hobbies, etc., before using the service. The survey results are in good agreement with a large pool of studies on trust in the sharing economy [72].

\section{Discussion}

We highlighted several articles that examine socio-economic and cultural differences that affect consumer willingness to use sharing platforms to compare our results with those of other authors. We have identified several advantages for cities in the Russian Federation, similarly to Nadeem [4] who believes that the shared consumption economy contributes to a more efficient allocation of resources, reduces the environmental burden and increases the level of trust in society. We attributed the reduced congestion to the advantages of sharing mobility, which leads to a decrease in environmental pollution and an improvement in the ecological situation, and, consequently, to a higher quality of life for citizens. Besides, the refusal to own a private car leads to a decrease in the load of urban parking spaces. Alongside other authors [72], we identified some shortcomings in the functioning of carsharing associated with the risks of unfair treatment of other people's property, dangerous driving, the risk of cheating the system, etc. These drawbacks lead to the increased distrust of citizens, increased costs for companies providing these services and ultimately affect the cost of services.

Our study showed a quantitative difference in the use of ridesharing in the Russian Federation and other countries. Compared to world data, a similar trend was observed in Russia at the average range and price of the trip in 2018. In terms of the number of users of this service, Russia lags behind some other countries, no more than $1 \%$ of the country's inhabitants use it each year. But the annual growth according to the TIAR centre is more than $50 \%$. The lag is due to the low penetration of ridesharing in intercity trips due to unresolved legal issues regarding illegal business. At the government level, proposals are being considered for legislative regulation of the ridesharing market. This confirms the opinions of other authors, such as Ma et al. [73]. They studied the joint creation of value between users (consumers) and firms (manufacturers) in the everyday use of mobility in China. In their opinion, the strengthening of state enforcement of bikesharing and electricity sharing rules means that vehicle sharing can attract more potential users. The authors of another study on bicycle sharing in China [74] came to a similar conclusion based on a survey of 387 users of shared bicycles.

Cheng and colleagues [72] interviewed a total of 92 drivers who shared on the leading platform in China to find out which negative experiences would prevent the consumer from further participating in this mobility scheme and did not identify any cultural differences. Nevertheless, they also advise tightening state control over improper user behaviour. In our opinion, such a clear preference for strict government regulation when solving problems arising between users of shared access platforms can be considered a cultural feature of China. Davidson and colleagues [75] studied the cultural background 
of potential users of sharing platforms in India and the USA. By online cross-country surveys, they determined the factors that influence the willingness to participate in the couch-sharing program. They concluded that Indian consumers are much faster and easier to motivate to use sharing models due to the rich historical experience of resource sharing and global collectivism. The only study we could find which provides data on Russia compared with other countries is Gupta's paper with co-authors [76]. The authors polled 1163 undergraduate students from business schools in 11 countries (China, India, Jamaica, Namibia, Pakistan, Philippines, Russia, South Korea, Turkey, United Kingdom, USA). They revealed the dependence of the willingness of consumers to use sharing platforms on such cultural differences as collectivism, uncertainty avoidance, masculinism and power distance. The authors attributed Russia, along with Turkey and South Korea, to countries with high uncertainty avoidance, where sharing platforms should focus primarily on lowering (potential) peer providers' perceptions of risk to encourage participation.

Our study results are consistent with the findings of [76] and also determine the reduced risk of using sharing platforms as one of the main directions for attracting potential users. In our opinion, an essential driver for the growth of a sharing economy based on digital platforms is the involvement of young people who are fluent in using the Internet, the principles of operation of digital platforms and mobile applications. Thus, our analysis results demonstrated that young people living in large cities quick to become involved in sharing processes. Besides, in Krasnodar, the percentage of users of C2C sites is more significant than in Moscow. We attribute this to the lower incomes of the population. More carsharing was used in Moscow. In our opinion, this is due to the development of carsharing in the Moscow region and the interest of city authorities.

On the contrary, ridesharing prevails in Krasnodar, since there it is used over longer distances than in the city environment. It would be interesting for future studies to compare indicators taking into account the incomes of households, other large and small cities, and the growth of the Internet and mobile communication penetration into the regions. The data obtained by us on the common use of coworking spaces confirms the opinion of authors $[4,51,72]$ who believe that not all consumers can quickly switch to new forms of consumption, due to various barriers, including knowledge, competencies and experience.

The study showed that digital sharing platforms in the Russian Federation would develop further with the increasing penetration of the Internet into small cities and remote areas, developing the population's digital competencies. Besides, the results of our survey of the most promising group of users of sharing models showed that a significant incentive to use a particular sharing platform is the experience gained in the course of study. The opportunities provided by educational institutions for the use of various sharing models help reduce the barrier of lack of trust in such a model, understand and experience its advantages through personal experience, develop the necessary skills and create stable habits for future use. The authors believe that the positive experience of being involved in the use of sharing models is formed not so much in the framework of educational courses but through the proper organisation of the university campus and student communications. Thus, modern universities can be considered platforms for the introduction and development of innovative models of the sharing economy; it is possible to implement latent training in their use. This conclusion can be used to develop programs to stimulate the development of sharing platforms in Russia and other countries with the proper development of the Internet.

\section{Conclusions}

To the best of our knowledge, the present work is essentially a pilot study in this area in the Russian Federation. It is aimed at expanding the discussion on the problems of sustainable development of the country in all its diversity, including sharing processes-in contrast with the interpretation of sustainable development only as economic growth. The study showed that digital sharing platforms are becoming an essential component of a circular economy and contribute to the country's sustainable development as a whole. Universities have all the necessary infrastructural 
conditions for the implementation and demonstration of sharing projects and their sites can become a driver for the further development of the sharing economy. The experience of using sharing models in the learning process allows the consumer to lower the barrier of mistrust, test the benefits and create sustainable models of consumer behaviour for the future. These findings set the direction for further improving international and Russian sharing platforms in terms of attracting new users. The study results can also contribute to the discussion of the Russian Federation's socio-economic strategy.

Author Contributions: Conceptualisation and methodology, S.R. (Svetlana Revinova); software, S.R. (Svetlana Revinova); validation, S.R. (Svetlana Revinova), K.G. and S.R. (Svetlana Ratner); formal analysis, I.L.; investigation, S.R. (Svetlana Revinova); resources, I.L.; data curation, S.R. (Svetlana Ratner); writing —original draft preparation, S.R. (Svetlana Revinova); writing-review and editing, S.R. (Svetlana Ratner); visualisation, K.G.; supervision, S.R. (Svetlana Ratner); project administration, I.L.; funding acquisition, I.L. All authors have read and agreed to the published version of the manuscript.

Funding: The publication has been prepared with the support of the «RUDN University Program 5-100».

Conflicts of Interest: The authors declare no conflict of interest.

\section{Appendix A}

Table A1. Questionnaire

Criterion/Question
Age
Gender
Country
Do you know what carsharing is? (YES / NO)
Have you ever used carsharing? If so, through which service?
Are you planning to use a carsharing service soon? (YES / NO)
Do you know what homesharing is? (YES / NO)
Have you ever used homesharing? If so, through which service?
Do you plan to use homesharing soon? (YES / NO)
Do you know what ridesharing is? (YES / NO)
Have you ever used ridesharing? If so, through which service?
Do you plan to take advantage of ridesharing soon? (YES NO)
Do you know what coworking is? (YES / NO)
Have you ever used coworking? If so, where was it?
Do you plan to use coworking soon? (YES / NO)
Have you ever sold products online? If so, through which website?
If not, do you plan to take this opportunity? (YES / NO)
If not, do you plan to take this opportunity? (YES / NO)
Have you rented products online? If so, through which website?
If not, do you plan to take this opportunity? (YES / NO)
Do you know what foodsharing is? (YES / NO)
Have you ever used a street bike rental? If so, in which cities?
Do you know what Airbnb does? (YES / NO)
Do you know what BlaBlaCar does? (YES / NO)
Do you know what Avito does? (YES / NO)
Have you ever bought products online from individuals? If so, through which website?

\section{References}

1. The Sustainable Development Agenda. 2020. Available online: https://www.un.org/sustainabledevelopment/ development-agenda/ (accessed on 12 January 2020).

2. Schröder, P.; Anantharaman, M.; Anggraeni, K.; Foxon, T.J. The Circular Economy and the Global South: Sustainable Lifestyles and Green Industrial Development; Taylor and Francis: London, UK, 2019; pp. 1-216. [CrossRef]

3. Curtis, S.; Lehner, M. Defining the Sharing Economy for Sustainability. Sustainability 2019, 11, 567. [CrossRef] 
4. Nadeem, W.; Juntunen, M.; Shirazi, F.; Hajli, N. Consumers' value co-creation in sharing economy: The role of social support, consumers' ethical perceptions and relationship quality. Technol. Forecast. Soc. Chang. 2020, 151, 119786. [CrossRef]

5. Analytical Center under the Government of the Russian Federation. Newsletter on Current World Economy Trends 47; March 2019. Available online: https://ac.gov.ru/archive/files/publication/a/21585.pdf (accessed on 2 February 2020).

6. Schwab, K. The Fourth Industrial Revolution; Eksmo Publishing House: Moscow, Russia, 2018.

7. Pakhomova, N.; Richter, K.; Vetrova, M. Transition to circular economy and closedloop supply chains as driver of sustainable development. St Petersburg Univ. J. Econ. Stud. 2017, 33, 244-268. [CrossRef]

8. Hofmann, S.; Sæbø, Ø.; Braccini, A.; Za, S. The public sector's roles in the sharing economy and the implications for public values. Gov. Inf. Q. 2019, 36, 101399. [CrossRef]

9. Hossain, M. Sharing economy: A comprehensive literature review. Int. J. Hosp. Manag. 2020, 87, 102470. [CrossRef]

10. Botsman, R.; Rogers, R. What's Mine is Yours the Rise of Collaborative Consumption; HarperBusiness: New York, NY, USA, 2010.

11. Benkler, Y. Sharing Nicely: On Shareable Goods and the Emergence of Sharing as a Modality of Economic Production. Yale Law J. 2004, 114, 273. [CrossRef]

12. Gomonov, K.; Balashova, S.; Matyushok, V. The relationship of socio-economic development and the drivers of green economy. Int. Days Stat. Econ. 2019, 2019. [CrossRef]

13. Lamberton, C.; Rose, R. When is Ours Better than Mine? A Framework for Understanding and Altering Participation in Commercial Sharing Systems. SSRN Electron. J. 2012. [CrossRef]

14. Acquier, A.; Daudigeos, T.; Pinkse, J. Promises and paradoxes of the sharing economy: An organizing framework. Technol. Forecast. Soc. Chang. 2017, 125, 1-10. [CrossRef]

15. Li, Y.; Bai, X.; Xue, K. Business modes in the sharing economy: How does the OEM cooperate with third-party sharing platforms? Int. J. Prod. Econ. 2020, 221, 107467. [CrossRef]

16. Yang, M.; Evans, S.; Vladimirova, D.; Rana, P. Value uncaptured perspective for sustainable business model innovation. J. Clean. Prod. 2017, 140, 1794-1804. [CrossRef]

17. Richardson, L. Performing the sharing economy. Geoforum 2015, 67, 121-129. [CrossRef]

18. Tura, N.; Keränen, J.; Patala, S. The darker side of sustainability: Tensions from sustainable business practices in business networks. Ind. Mark. Manag. 2019, 77, 221-231. [CrossRef]

19. Rong, K.; Xiao, F.; Wang, Y. Redundancy in the sharing economy. Resour. Conserv. Recycl. 2019, 151, 104455. [CrossRef]

20. Geissinger, A.; Laurell, C.; Öberg, C.; Sandström, C. How sustainable is the sharing economy? On the sustainability connotations of sharing economy platforms. J. Clean. Prod. 2019, 206, 419-429. [CrossRef]

21. Ciulli, F.; Kolk, A. Incumbents and business model innovation for the sharing economy: Implications for sustainability. J. Clean. Prod. 2019, 214, 995-1010. [CrossRef]

22. Laukkanen, M.; Tura, N. The potential of sharing economy business models for sustainable value creation. J. Clean. Prod. 2020, 253, 120004. [CrossRef]

23. Scavarda, A.; Daú, G.; Felipe Scavarda, L.; Duarte Azevedo, B.; Luis Korzenowski, A. Social and ecological approaches in urban interfaces: A sharing economy management framework. Sci. Total Environ. 2020, 713, 134407. [CrossRef]

24. How Much Is the Sharing Economy Worth to GDP? 2020. Available online: https://www.weforum.org/ agenda/2016/10/what-s-the-sharing-economy-doing-to-gdp-numbers/ (accessed on 11 February 2020).

25. Nikitina, B. Circular and Sharing Economy Practices and Their Implementation in Russian Universities. Lect. Notes Netw. Syst. 2019, 19-26. [CrossRef]

26. Dillahunt, T.; Malone, A. The Promise of the Sharing Economy among Disadvantaged Communities. In Proceedings of the 33rd Annual ACM Conference on Human Factors in Computing Systems-CHI '15, Seoul, Korea, 18-23 April 2015. [CrossRef]

27. Fang, B.; Ye, Q.; Law, R. Effect of sharing economy on tourism industry employment. Ann. Tour. Res. 2016, 57, 264-267. [CrossRef] 
28. Probst, L.; Frideres, L.; Pedersen, B.; Lidé, S. Collaborative Economy. Collaborative Production and the Maker Economy; European Commission, Directorate-General Growth: Brussels, Belgium, 2015; Available online: https://ec.europa.eu/docsroom/documents/13423/attachments/1/translations/en/renditions/native (accessed on 11 February 2020).

29. Menor-Campos, A.; García-Moreno, M.; López-Guzmán, T.; Hidalgo-Fernández, A. Effects of Collaborative Economy: A Reflection. Soc. Sci. 2019, 8, 142. [CrossRef]

30. Möhlmann, M. Collaborative consumption: Determinants of satisfaction and the likelihood of using a sharing economy option again. J. Consum. Behav. 2015, 14, 193-207. [CrossRef]

31. Sutherland, W.; Jarrahi, M. The sharing economy and digital platforms: A review and research agenda. Int. J. Inf. Manag. 2018, 43, 328-341. [CrossRef]

32. Hu, J.; Liu, Y.; Yuen, T.; Lim, M.; Hu, J. Do green practices really attract customers? The sharing economy from the sustainable supply chain management perspective. Resour. Conserv. Recycl. 2019, 149, 177-187. [CrossRef]

33. Baumber, A.; Scerri, M.; Schweinsberg, S. A social licence for the sharing economy. Technol. Forecast. Soc. Chang. 2019, 146, 12-23. [CrossRef]

34. Yi, J.; Yuan, G.; Yoo, C. The effect of the perceived risk on the adoption of the sharing economy in the tourism industry: The case of Airbnb. Inf. Process. Manag. 2020, 57, 102108. [CrossRef]

35. Huang, C.; Liu, S.; Hsu, N. Understanding Global Food Surplus and Food Waste to Tackle Economic and Environmental Sustainability. Sustainability 2020, 12, 2892. [CrossRef]

36. David, M. The Collaborative Economy in China, Frontline of the Sharing Economy. 2020. Available online: https://daxueconsulting.com/exploding-collaborative-economy-in-china (accessed on 10 February 2020).

37. Bergh, A.; Funcke, A.; Wernberg, J. Timbro Sharing Economy Index. 2020. Available online: https: //timbro.se/allmant/timbro-sharing-economy-index/ (accessed on 2 June 2020).

38. Corporate-Body. GROW: Directorate-General for Internal Market, n. Study to Monitor the Economic Development of the Collaborative Economy at Sector Level in the 28 EU Member States: Final Report. 2020. Available online: https:/publications.europa.eu/en/publication-detail/-/publication/0cc9aab6-7501-11e89483-01aa75ed71a1/language-en/format-PDF/source-72448580 (accessed on 2 February 2020).

39. Sharing or Paring? Growth of the Sharing Economy. 2020. Available online: https://www.pwc.com/hu/en/ kiadvanyok/assets/pdf/sharing-economy-en.pdf (accessed on 2 February 2020).

40. Barbu, C.; Bratu, R.; Sîrbu, E. Business Models of the Sharing Economy. Rev. Int. Comp. Manag. 2018, 19, 154-166. [CrossRef]

41. Pouri, M.; Hilty, L. Conceptualizing the Digital Sharing Economy in the Context of Sustainability. Sustainability 2018, 10, 4453. [CrossRef]

42. Wirtz, J.; So, K.; Mody, M.; Liu, S.; Chun, H. Platforms in the peer-to-peer sharing economy. J. Serv. Manag. 2019, 30, 452-483. [CrossRef]

43. Li, Y.; Lim, M.; Tan, Y.; Lee, S.; Tseng, M. Sharing economy to improve routing for urban logistics distribution using electric vehicles. Resour. Conserv. Recycl. 2020, 153, 104585. [CrossRef]

44. eBay Annual Report 2018. 2019. Available online: https:/ebay.q4cdn.com/610426115/files/doc_financials/ financials/2018/annual/2018_eBay_Annual_Report.pdf (accessed on 2 February 2020).

45. Vehicles \& Road Traffic | Statista. 2020. Available online: https://www.statista.com/markets/419/topic/487/ vehicles-road-traffic/ (accessed on 14 January 2020).

46. Ratner, S.; Zaretskaya, M. Forecasting the Ecology Effects of Electric Cars Deployment in Krasnodar Region: Learning Curves Approach. J. Environ. Manag. Tour. 2018, 9, 82. [CrossRef]

47. Zmyślony, P.; Leszczyński, G.; Waligóra, A.; Alejziak, W. The Sharing Economy and Sustainability of Urban Destinations in the (Over) tourism Context: The Social Capital Theory Perspective. Sustainability 2020, 12, 2310. [CrossRef]

48. Airbnb. 2020. Available online: https://www.airbnb.com/trust?locale=en\&_set_bev_on_new_domain= 1591093978_MGE0NmZmNTRmNDI2 (accessed on 14 January 2020).

49. Adamiak, C. Current state and development of Airbnb accommodation offer in 167 countries. Curr. Issues Tour. 2019, 1-19. [CrossRef] 
50. Ratner, S.; Iosifov, V. Eco-Management and Eco-Standardization in Russia: The Perspectives and Barriers for Development. J. Environ. Manag. Tour. 2017, 8, 247-258. [CrossRef]

51. Lutz, C.; Hoffmann, C.; Bucher, E.; Fieseler, C. The role of privacy concerns in the sharing economy. Inf. Commun. Soc. 2017, 21, 1472-1492. [CrossRef]

52. Pawlicz, A. Pros and cons of sharing economy regulation. Implications for sustainable city logistics. Transp. Res. Procedia 2019, 39, 398-404. [CrossRef]

53. Stop Food Waste-Food Safety-European Commission. 2020. Available online: https://ec.europa.eu/food/ safety/food_waste/stop_en (accessed on 2 March 2020).

54. Federal State Statistic Service. 2020. Available online: https://eng.gks.ru (accessed on 31 May 2020).

55. Association of Electronic Communications (RAEC). Co-Consumption Economics in Russia 2018. Available online: https://raec.ru/activity/analytics/9845/ (accessed on 31 March 2020).

56. Millennials Infographic. 2020. Available online: https:/www.goldmansachs.com/insights/archive/ millennials/ (accessed on 15 March 2020).

57. Rosstat. Available online: https://www.gks.ru/folder/210/document/13251 (accessed on 15 March 2020).

58. Yin, R. Case Study Research: Design and Methods; Sage: Thousand Oaks, CA, USA, 2002.

59. The National Program “Digital Economy of the Russian Federation” №. 1632-p, July 28, 2017. Available online: http://static.government.ru/media/files/9gFM4FHj4PsB79I5v7yLVuPgu4bvR7M0.pdf (accessed on 31 January 2020).

60. Revinova, S.; Lazanyuk, I. Internet and Education: Project Approach. ICERI2019 Proc. 2019. [CrossRef]

61. Data Insight, Avito. C2C on the Russian Internet. Online Trade between Individuals. 2019. Available online: http://datainsight.ru/c2c_Avito_2019 (accessed on 15 March 2020).

62. Avito. Integrated Report; 2018; Available online: https://www.avito.ru/company (accessed on 10 February 2020).

63. Forbes New toy: How Mail.ru Group Makes Money on the Online Classified Ads Service. Available online: https://www.forbes.ru/biznes/369865-novaya-igrushka-kak-mailru-group-zarabatyvaet-na-serviseonlayn-obyavleniy (accessed on 15 February 2020).

64. DataInsigt. E-commerce in Russia. 2019. Available online: http://datainsight.ru/sites/default/files/DI_ Ecommerce2019.pdf (accessed on 15 February 2020).

65. BlaBlaCar. Available online: https://blog.blablacar.ru/about-us (accessed on 15 February 2020).

66. Sberbank. 28 March 2019. Available online: https://www.sberbank.com/ru/news-and-media/press-releases/ (accessed on 1 February 2020).

67. Li, I.; Pastushin, A. Airbnb first disclosed the volumes of housing rental in Russia//RBC, 07/08/2017. Available online: https://www.rbc.ru/technology_and_media/08/07/2017/595f46b39a79479492a04647 (accessed on 24 January 2020).

68. Bouncken, R.; Reuschl, A. Coworking-spaces: How a phenomenon of the sharing economy builds a novel trend for the workplace and for entrepreneurship. Rev. Manag. Sci. 2016, 12, 317-334. [CrossRef]

69. kovorkingi.ru. Available online: https://www.kovorkingi.ru/ (accessed on 15 February 2020).

70. Sherunkova, O. Fashion for Foodsharing: Free Food will Save Russia. 2020. Available online: https: //m.gazeta.ru/business/2020/01/16/12913076.shtml (accessed on 25 January 2020).

71. RUDN University. Available online: http://www.rudn.ru/media/news/karera/v-rudn-vpervye-otkryto-coworking-space (accessed on 24 January 2020).

72. Cheng, X.; Su, L.; Yang, B. An investigation into sharing economy enabled ridesharing drivers' trust: A qualitative study. Electron. Commer. Res. Appl. 2020, 40, 100956. [CrossRef]

73. Ma, Y.; Rong, K.; Luo, Y.; Wang, Y.; Mangalagiu, D.; Thornton, T. Value Co-creation for sustainable consumption and production in the sharing economy in China. J. Clean. Prod. 2019, 208, 1148-1158. [CrossRef]

74. Chi, M.; George, J.; Huang, R.; Wang, P. Unraveling sustainable behaviors in the sharing economy: An empirical study of bicycle-sharing in China. J. Clean. Prod. 2020, 260, 120962. [CrossRef] 
75. Davidson, A.; Habibi, M.; Laroche, M. Materialism and the sharing economy: A cross-cultural study of American and Indian consumers. J. Bus. Res. 2018, 82, 364-372. [CrossRef]

76. Gupta, M.; Esmaeilzadeh, P.; Uz, I.; Tennant, V. The effects of national cultural values on individuals' intention to participate in peer-to-peer sharing economy. J. Bus. Res. 2019, 97, 20-29. [CrossRef]

(C) 2020 by the authors. Licensee MDPI, Basel, Switzerland. This article is an open access article distributed under the terms and conditions of the Creative Commons Attribution (CC BY) license (http://creativecommons.org/licenses/by/4.0/). 